\title{
A Polymerase Chain Reaction Protocol for the Detection of Xanthomonas albilineans, the Causal Agent of Sugarcane Leaf Scald Disease
}

\author{
Y.-B. Pan, Research Plant Geneticist, M. P. Grisham, Research Plant Pathologist, and D. M. Burner, Research \\ Plant Geneticist, USDA-ARS, Southern Regional Research Center, Sugarcane Research Unit, P.O. Box 470, \\ Houma, LA 70361
}

\begin{abstract}
Pan, Y.-B., Grisham, M. P., and Burner, D. M. 1997. A polymerase chain reaction protocol for the detection of Xanthomonas albilineans, the causal agent of sugarcane leaf scald disease. Plant Dis. 81:189-194.

A polymerase chain reaction (PCR) protocol was developed that amplified a 360-bp DNA product unique to Xanthomonas albilineans $(\mathrm{X} a$ ), the causal agent of sugarcane leaf scald disease. The assay utilizes previously described PCR primers that target the intergenic transcribed spacer (ITS) region between the $16 \mathrm{~S}$ and $23 \mathrm{~S}$ rRNA genes. Primer pair Ala4/L1 allowed amplification of a 360-bp DNA fragment from $71 \mathrm{Xa}$ strains including representatives of serovars I, II, and III. Fragments of different sizes were also amplified from three unidentified saprophytic bacteria from sugarcane. $X a$ could be detected at a lower bacterial concentration with the PCR protocol than with a serological dot blot assay. With PCR, as little as $1.25 \mathrm{pg}$ of $\mathrm{Xa}$ genomic DNA (125 fg if followed by Southern blot hybridization), or as few as 0 to 5 CFU of Xa per reaction were detected from infected sugarcane sap and leaf diffusate. Five CFU of Xa per reaction were detected from suspension culture. The PCR protocol provides a rapid, reliable, and economical tool for routine detection and identification of $X a$.
\end{abstract}

Xanthomonas albilineans (Xa), a gramnegative bacterium, colonizes the vascular system of leaves, stalks, and roots $(29,32)$ and causes leaf scald of sugarcane ( $\mathrm{Sac}$ charum spp. hybrids). The disease was first reported in the 1920s (29) and has since been reported in most sugarcane regions $(29,32)$. The disease was first observed in the continental U.S. in Florida in 1967 (21) but was relatively unimportant until 1989 , when incidence and distribution increased rapidly (7). Leaf scald was first detected in Louisiana in November 1992 (11) and in Texas in May 1993 (17).

The leaf scald pathogen is transmitted primarily by planting infected stalks and by mechanical spread on contaminated cutting implements (29). There is increasing evidence for spread by aerial means, by

Corresponding author: Y.-B. Pan;

Telephone: (504) 853-3165; Fax (504) 868-8369;

E-mail: ypan@nola.srrc.usda.gov

Product names and trademarks are mentioned to report factually on available data; however, the USDA neither guarantees nor warrants the standard of the product, and the use of the name by USDA does not imply the approval of the product to the exclusion of others that may also be suitable.

Accepted for publication 6 November 1996.

Publication no. D-1996-1217-04R

This article is in the public domain and not copyrightable. It may be freely reprinted with customary crediting of the source. The American Phytopathological Society, 1997. leaf to leaf contact, by root to root contact, and by soil infestation $(3,19)$. The disease is potentially serious and may cause significant loss to cane yield and sugar quality $(15,29)$. In its acute phase, the pathogen causes mature stalks to suddenly wilt and die. Latent infections of susceptible cultivars, a characteristic of the disease, may allow build-up and spread of the pathogen. As a result, sensitive and reliable methods are needed for the detection of the pathogen in apparently symptomless plants.

Diagnosis of leaf scald is currently based primarily on visible symptoms (29), isolation of the pathogen from infected sugarcane on selective media $(6,8,34)$, and serological methods including immunofluorescence, agglutination, dot and tissue blot, and enzyme-linked immunosorbent assay (ELISA) with monoclonal or polyclonal antibodies $(2,6,8,24,31,37)$. Because of latency, visual symptoms of leaf scald may not appear. Detection of the pathogen from asymptomatic plants by isolation and serological procedures may also be unreliable because of low titers or uneven distribution of the pathogen within plant tissues $(2,6,8,16,30,37)$. The detection limits are about $10^{5} \mathrm{CFU}$ per $\mathrm{ml}$ for isolation $(6,8,9)$, and at least $10^{5} \mathrm{CFU}$ per $\mathrm{ml}$ for serological methods $(2,6,16)$.

The polymerase chain reaction (PCR) $(13,28)$ has been successfully used to detect xanthomonads including $X$. campestris pv. citri (12), X. campestris pv. phaseoli (1), and $X$. campestris pv. vesicatoria (23), and for the detection of sugarcane mosaic virus, Fiji disease virus, and bacilliform virus $(5,26,35)$. Recently, the length and sequence polymorphism of the intergenic transcribed spacer (ITS) region revealed by PCR was used to detect, identify, and differentiate bacterial species $(4,14,18,22,25$, 27,39). Generic primer pair L1/G1 was developed to amplify the $16 \mathrm{~S}$ to $23 \mathrm{~S}$ spacer regions for over 300 bacterial strains (18). Consensus tRNA-PCR primers T3A, T5A, and T5B (27) were used to amplify the region between tRNA genes to produce genomic fingerprints applicable to the identification of the organism. An $\mathrm{Xa}$ specific tRNA primer, Ala4, located in the ITS of the $16 \mathrm{~S}$ to $23 \mathrm{~S}$ ribosomal DNA region was recently designed (14). A product of $70 \mathrm{bp}$ was reportedly amplified from 14 $\mathrm{X} a$ strains by $\mathrm{PCR}$ with primer pair Ala4/Ile2. Ile2 is a nonspecific tRNA primer (14).

The objectives of this study were to (i) test three sets of primers-L1/G1 (18), T3A/T5A (39), and T3A/T5B (39)-for specificity to $X a$, (ii) test the specificity of Ala4 (14) in combination with L1 to $X a$, and (ii) develop a sensitive PCR protocol that is rapid, reliable, and economical in detecting $\mathrm{Xa}$ in infected sugarcane tissue.

\section{MATERIALS AND METHODS}

Bacterial strains. Seventy-one strains of $X a$ of worldwide origin were included in the study. Twelve of these (Xa1,Xa-043, $X a-044, X a-045, X a-046, X a-047, X a-048$, GT2, 36KT, 320KT, 419KT, and Thibod) were isolated in Louisiana and were maintained as live cultures on XAS medium (8). Pathogenicity and taxonomy of these strains were verified by standard procedures $(8,20)$. The remaining 59 strains were collected as genomic DNA samples. Five of these $(X a-3$, FB500, FB576, FB577, FB580) were from J. C. Comstock (USDA/ARS, Canal Point, FL), eight (3508, 3510, 3511, 1512, 3514, 3516, 3517, and 3518) were from A. Dookun (Mauritius Sugar Industry Research Institute, Réduít, Mauritius), three (FB578, FB579, and ATCC \# 33915) were from N. W. Schaad (USDA/ARS, Fort Detrick, $\mathrm{MD}$ ), and 43 were from S. Schenck (Hawaiian Sugar Planters' Association, Aiea, HI). The latter 43 strains included one from Australia (R5161), one from Burkina Faso (HV5), three from Brazil (IBSBF326, IBSBF654, and IBSBF740), two from Fiji (196-86, 196-87), six from Florida (CP3, CP5, CP6, 91-164, 91-225, 
and 91-231), 7 from Guadeloupe (G7, G44, GPE2, GPE3, GPE6, GPE9, and GPE108), 12 from Hawaii (A3182, A3183, A3184, A3185, A3186, A3189, A3494, A3589, A3590, A4009, A4086, and A4158), one from Ivory Coast (C1-35), three from Oahu (A3805, A3806, and A3993), two from Papua New Guinea (A3269, AA3270), one from Reunion $(\mathrm{Xa28})$, one from St. Kitts (STK3), one from S. Africa (SA-P1), one from Taiwan (ROC1-890), and one of unknown origin (A4394). Among these strains, two (CP5 and G44) had previously been shown to belong to serovar I, two (C1-35 and HV5) to serovar II, and two (G7 and STK3) to serovar III (31).

Seventeen xanthomonad strains isolated from other plant species were also tested. These included eight $X$. oryzae subsp. oryzae strains (Xoo-017, Хоo-018, X8-1A, CXO 1, NXO 101, MXO 97, PXO 68, and $P X O$ 79) from rice, two $X$. campestris strains $(X c-033$ and $X c-039)$ and three $X$. campestris pv. translucens strains (Xc-021, Xct-90-01, and Xc-90-38) from wheat, one $X$. campestris pv. translucens strain $(X c-$ 90-15) from Bromus spp., and three $X$. fragariae strains (Xf-029, Xf-041, and Xf-042) from strawberry. Seven bacterial saprophytes (243, CA1, 22-19-6s, GT1, 24-2i, 19-26-1a, 23-25-6a) isolated locally from sugarcane and Clavibacter xyli subsp. xyli DNA were also included in the study. $C$. $x y l i$ subsp. $x y l i$ is another common xylemlimited bacterial pathogen of sugarcane.

Genomic DNA mini-extraction. Bacterial cells grown in $1.5 \mathrm{ml}$ of XAS broth were collected in microfuge tubes by spinning at $1,500 \times g$ for $8 \mathrm{~min}$, washed with $0.5 \mathrm{ml}$ of STE buffer (100 mM NaCl, 10 mM Tris [pH 8.0], 1 mM EDTA [pH 8.0]), and lysed in $400 \mu \mathrm{l}$ of freshly prepared lysis buffer $(20 \mu \mathrm{l}$ of $1 \mathrm{M}$ Tris [pH 8.0], $40 \mu \mathrm{l}$ of $0.5 \mathrm{M}$ EDTA [pH 8.0], $120 \mu \mathrm{l}$ of $10 \%$ sodium dodecyl sulfate [SDS], $4 \mu \mathrm{l}$ of 2 mercaptoethanol, and $216 \mu \mathrm{l}$ of $\mathrm{ddH}_{2} \mathrm{O}$ ). The lysate mix was incubated at $65^{\circ} \mathrm{C}$ for 2 $\mathrm{h}$ with occasional mixing and extracted twice with $400 \mu \mathrm{l}$ of phenol/chloroform/ isoamyl alcohol (25:24:1, vol/vol/vol). Nucleic acids were precipitated from the aqueous phase by adding $1 / 10 \mathrm{vol}$ of $3 \mathrm{M}$ sodium acetate plus 2 vol of $95 \%$ ethanol. The DNA/RNA fiber was transferred with a sterile pipette tip to a fresh tube, washed with $75 \%$ ethanol, and dissolved in $100 \mu \mathrm{l}$ of TE buffer $(10 \mathrm{mM}$ Tris- $\mathrm{HCl}, 1 \mathrm{mM}$ EDTA, pH 8.0) with $10 \mu \mathrm{g}$ of RNase A. After $1 \mathrm{~h}$ at $37^{\circ} \mathrm{C}, 1 \mu \mathrm{l}$ of $10 \%$ SDS and 10 $\mu \mathrm{g}$ of proteinase $\mathrm{K}$ were added. The sample was incubated at $60^{\circ} \mathrm{C}$ for $1 \mathrm{~h}$ and extracted by phenol/chloroform/isoamyl alcohol, and the DNA precipitated by the addition of $100 \mu \mathrm{l}$ of $4 \mathrm{M}$ ammonium acetate and $600 \mu$ of $95 \%$ ethanol. The DNA pellet was rinsed with $75 \%$ ethanol, dissolved in $50 \mu \mathrm{l}$ of TE, and stored at $-20^{\circ} \mathrm{C}$. DNA concentration was determined in a Model 340 spectrophotometer (SequoiaTurner Corp., Mountain View, CA). DNA samples diluted to $20 \mu \mathrm{g} / \mathrm{ml}$ were used in PCR.

Chemicals and reagents were purchased from Sigma Chemical Co. (St. Louis, MO) unless otherwise noted.

PCR primers. Four pairs of PCR primers, located either adjacent to (L1/G1) (18), or inside-T3A/T5A (39), T3A/T5B (39), and Ala4/Ile2 (14) - the ITS of the 16S to 23S rRNA genes, were tested for their specificity to $X a$. In addition, primer pairs Ala4/L1 and Ile2/G1 were tested. The sequences of these primers are as follows $\left(5^{\prime} \rightarrow 3^{\prime}\right)$ : L1 (CAA GGC ATC CAC CGT); G1 (GAA GTC GTA ACA AGG); T3A (GGG GGT TCG AAT TCC CGC CGG CCC CA); T5A (AGT CCG GTG CTC TAA CCA ACT GAG); T5B (AAT GCT CTA CCA ACT GAA CT); ALA4 (CCC GAC TGG CTC CAC CAC TG) ; and Ile2 (CCT TAT CAG GGG TGC GCT C). All primers were synthesized by International DNA Technologies (IDT, Coralville, IA) and used according to company specifications.

PCR amplification and analysis of PCR products. Reaction mixtures were assembled on ice and started in a preheated $\left(95^{\circ} \mathrm{C}\right)$ PTC-100 Programmable Thermal Controller (Model 60, MJ Research, Inc., Watertown, MA). Each reaction mixture in $25-\mu \mathrm{l}$ volume contained $50 \mathrm{mM} \mathrm{KCl}, 2$ $\mathrm{mM} \mathrm{MgCl} 2,10 \mathrm{mM}$ Tris-HCl (pH 8.3), 0.2 $\mathrm{mM}$ each of dATP, dTTP, dGTP, and dCTP, $1 \mu \mathrm{M}$ each primer, 0.625 units of native Taq DNA polymerase (Perkin Elmer, Foster City, CA), and test sample (25 ng of genomic DNA or $0.625 \mu \mathrm{l}$ of cell culture, sap, or diffusate), and was overlaid with two drops of mineral oil.

Genomic DNA from $18 \mathrm{Xa}$ strains (Xal, FB578, FB579, FB648, Хa-043, Хa-044, Xa-046, Хa-048, GT2, 36KT, 320KT, 419KT, Thibod, G44, HV5, C1-35, G7, and STK3), 13 other xanthomonad strains (Хoo-017, Хoo-018, X8-1A, Xf-029, Xf041, Xf-042, Xc-90-15, Xc33, Xc39, Xc-9038, Xc-021, Xcc-4, and Xct-90-01), C. xyli subsp. $x y l i$, and seven bacterial saprophytes (243, CA1, 22-19-6s, GT1, 24-2i, 19-261a, 23-25-6a) were tested for specificity of L1/G1, T3A/T5A, and T3A/T5B. L1/G1primed PCR was performed at $95^{\circ} \mathrm{C}$ for 5 min, 40 cycles of $94^{\circ} \mathrm{C}$ for $30 \mathrm{~s}, 50^{\circ} \mathrm{C}$ for $30 \mathrm{~s}$, and $72^{\circ} \mathrm{C}$ for $1 \mathrm{~min}$, and final extension at $72^{\circ} \mathrm{C}$ for $5 \mathrm{~min}$. For T3A/T5A- or T3A/T5B-primed PCR the following PCR program was used: $95^{\circ} \mathrm{C}$ for $5 \mathrm{~min}, 40 \mathrm{cy}-$ cles of $94^{\circ} \mathrm{C}$ for $30^{\circ} \mathrm{s}, 45^{\circ} \mathrm{C}$ for $30 \mathrm{~s}$, and $72^{\circ} \mathrm{C}$ for $2 \mathrm{~min}$, and final extension at $72^{\circ} \mathrm{C}$ for $7 \mathrm{~min}$.

For Ala4/L1-primed PCR, different programs were designed and tested by varying the number of cycles $(15,30$, or 40$)$, the annealing temperature $(45,50,55$, or $60^{\circ} \mathrm{C}$ ), and the holding time at either denaturing or annealing steps $(1,15$, or $30 \mathrm{~s})$. From these tests, the following PCR program was formulated for Ala4/L1- or Ile2/G1-primed PCRs: $95^{\circ} \mathrm{C}$ for $5 \mathrm{~min}, 30$ cycles of $94^{\circ} \mathrm{C}$ for $1 \mathrm{~s}, 55^{\circ} \mathrm{C}$ for $1 \mathrm{~s}$, and $72^{\circ} \mathrm{C}$ for $30 \mathrm{~s}$, and final extension at $72^{\circ} \mathrm{C}$ for $2 \mathrm{~min}$. Amplified PCR products were resolved by electrophoresis at $5.7 \mathrm{~V} / \mathrm{cm}$ either in $2 \%$ agarose or in $0.7 \%$ agarose $/ 0.65 \%$ Synergel(Diversified Biotech, Boston, MA) binary gels in $0.5 \times$ Trisborate-EDTA buffer for $2 \mathrm{~h}$, stained with ethidium bromide $(0.5 \mu \mathrm{g} / \mathrm{ml})$, and visualized with a UV transilluminator (Spectronics Corp., Westburg, NY).

Southern blot hybridizations. Resolved PCR products were denatured, neutralized, and transferred from gels by capillary action to Zeta-Probe nylon membranes (Bio-Rad Laboratories, Hercules, CA) (36). The blots were crosslinked in a Stratalinker UV Crosslinker (Stratagene, La Jolla, CA). Overnight pre-hybridizations were at $65^{\circ} \mathrm{C}$ in $6 \times \mathrm{SSPE}(1 \times \mathrm{SSPE}$ is $0.15 \mathrm{M} \mathrm{NaCl}, 10 \mathrm{mM} \mathrm{NaH} \mathrm{PO}_{4}$, and 1 $\mathrm{mM}$ EDTA [pH 7.4]) containing $0.02 \%$ Ficoll-400, $0.02 \%$ polyvinylpyrrolidone (PVP), $100 \mu \mathrm{g}$ of denatured salmon sperm DNA per ml, and $0.1 \%$ SDS (38). The 360bp Ala4/L1 fragment amplified from $\mathrm{Xal}$ genomic DNA was gel purified with the QIAquick Gel Extraction Kit (QIAGEN Inc., Chatsworth, CA) and labeled with ${ }^{32} \mathrm{P}-\mathrm{dCTP}$ with the Multiprime DNA Labelling System (Amersham, Arlington Heights, IL). Hybridizations were performed overnight at $68^{\circ} \mathrm{C}$ in $3 \times \mathrm{SSPE}$, $0.02 \%$ Ficoll-400, $0.02 \%$ PVP, $100 \mu \mathrm{g}$ of denatured salmon sperm DNA per ml, $0.1 \%$ SDS, and ${ }^{32} \mathrm{P}$-labeled probe. The blots were washed twice in $2 \times \mathrm{SSPE}+$ $0.1 \% \mathrm{SDS}$ at $68^{\circ} \mathrm{C}$, washed once in $0.2 \times$ $\mathrm{SSPE}+0.1 \% \mathrm{SDS}$ at room temperature, air dried, and exposed to Kodak X-OMAT film.

Detection limit of the PCR protocol. Ten-fold dilutions of $\mathrm{Xa}$ genomic DNA in the range of $25 \mathrm{ng}$ to $25 \mathrm{fg}$ and of $X a$ cells from suspension culture were prepared in sterile water. Ten-fold dilutions of sugarcane sap and leaf diffusate from infected plants were also prepared in sterile water. A $0.625-\mu \mathrm{l}$ aliquot from each dilution was mixed with $100 \mu \mathrm{l}$ of XAS broth and plated onto XAS agar medium. The plates were incubated at $28^{\circ} \mathrm{C}$ and CFU were counted 5 days after plating. Another $0.625-\mu \mathrm{l}$ aliquot was used directly in PCR reactions. A third $0.625-\mu \mathrm{l}$ aliquot was mixed with $100 \mu \mathrm{l}$ of $1 \times$ phosphate-buffered saline and transblotted by capillary action onto a nitrocellulose membrane for the dot blot enzyme immunoassay (DB-EIA) with an anti-Xa polyclonal antibody $(1: 4,000)$ (8). Antirabbit IgG conjugated with alkaline phosphatase $(1: 4,000)$ (Boehringer Mannheim, Indianapolis, IN) was used as secondary antibody according to the manufacturer's specifications. The plating, PCR, and dot blot serological assays were conducted three times.

PCR detection of $X a$ in infected sugarcane tissues. Sap was expressed and collected from stalks of each of 46 sugar- 
cane plants by forcing air through the excised basal internode with a small electric air pump. Thirty-one of these plants had been inoculated with $X a$ and 16 showed symptoms. The other 15 were uninoculated controls. A 50- $\mu \mathrm{l}$ aliquot from each of the 46 sap samples was pretreated by washing with $450 \mu \mathrm{l}$ of water and spinning at 3,400 $\times g$ for $5 \mathrm{~min}$; then the pellet was washed once more before being resuspended in 50 $\mu \mathrm{l}$ of water. A $0.625-\mu \mathrm{l}$ aliquot of the washed sample was tested by PCR. Aliquots of five randomly chosen samples that tested positive were retested by PCR but without the wash pretreatment.

Leaf samples were collected in the greenhouse from nine symptomatic seedlings, as indicated by the presence of white pencil line(s) (one or more narrow, white lines that extend longitudinally along the length of the leaf blade to the sheath), and 10 asymptomatic sugarcane seedlings that had all been inoculated with $\mathrm{Xal}$. One leaf from a healthy plant was used as control. Leaf samples were also collected in commercial fields from eight sugarcane plants showing the pencil-line symptom, and from another two plants showing atypical leaf symptoms, one with a stretch of white line localized near the midrib and the other with multiple stripes. Diffusate was prepared by soaking $500 \mathrm{mg}$ of leaf tissue overnight at room temperature in a microfuge tube with $1 \mathrm{ml}$ of sterile water. The diffusate was transferred to a fresh tube and spun at $3,400 \times g$. The pellet was washed twice and resuspended in $20 \mu \mathrm{l}$ of water. A $0.625-\mu l$ aliquot was used in the PCR reaction.

\section{RESULTS}

PCR products. A 540-bp product was amplified with primer pair L1/G1 from all $18 \mathrm{Xa}$ strains tested, 10 other xanthomonad strains, $C$. xyli subsp. xyli, and one saprophyte (22-19-6s). Products of larger sizes were amplified from Xct-90-01, Xc33, and Xc39 (590 bp), CA1 (620 bp), and GT1 (640 bp). Similarly, a nonspecific product of about $135 \mathrm{bp}$ was amplified with primer pair T3A/T5B from all $X a$ strains except C1-35, which produced an additional two fragments of about 320 and $600 \mathrm{bp}$. The 135 -bp product was also produced from GT1, Xct-90-01, Xc-033, Xc-039, and Xcc4. Similar results were observed with primer pair T3A/T5A (data not shown). A 260-bp fragment was amplified from the $X a 1$ genomic DNA with the nonspecific primer pair Ile2/G1.

When Ala4 was paired with L1, a unique 360-bp fragment was amplified from genomic DNA samples of all $71 \mathrm{Xa}$ strains tested, including those identified as serovars I (CP5, G44, and R8), II (C1-35 and HV5), and III (G7 and STK3) (e.g., Fig. 1A, lanes 2 to 7, 16, and 18). The 360bp product was also amplified directly from the bacteria cells of the 12 local $\mathrm{Xa}$ strains (data not shown). In contrast, no amplified products were observed from the genomic DNA of four saprophytes (GT1, 24-2i, 19-26-1a, and 23-25-6a) (Fig. 1A, lanes 11 to 14 ) or $C$. xyli subsp. xyli (Fig. 1A, lane 15). Although products of about 280,420 , and $460 \mathrm{bp}$ were amplified from three other bacterial saprophytes $(243,22-$ 19-6s, and CA1) (Fig. 1A, lanes 8, 10, and 9), these PCR products could be easily separated from the unique $X a$ product by electrophoresis either in a $2 \%$ agarose gel or in a $0.7 \%$ agarose $/ 0.65 \%$ Synergel binary gel (Fig. 1A, lane 18). These observations were confirmed by Southern blot hybridization with the Ala4/L1 fragment from $\mathrm{Xal}$ genomic DNA as the probe (Fig. 1B). After $20 \mathrm{~min}$ of exposure, strong images were seen in every $X a$ lane. No hybridization signal was detected in lanes of five saprophytes (243, GT1, 24-2i, 19-26tected in lanes of two other saprophytes (22-19-6s and CA1), indicating that there was some sequence homology between the probe derived from $X a$ and the PCR products derived from these two saprophytes.

No amplified products were detectable from the genomic DNA of any xanthomonad strains of non-sugarcane origin, either by ethidium bromide staining or by $1 \mathrm{a}$, and 23-25-6a). Weak signals were de-

Southern blot hybridization. However, when reactions were started on a thermal cycler that was not preheated to $95^{\circ} \mathrm{C}$, faint DNA bands were occasionally observed in lanes of some xanthomonad strains. In these cases, the amplified products from X8-1A, Xoo-017, Xoo-018, Xc-021, Xc-9015, Xc-90-38, Xf-029, Xf-041,Xf-042, and $X c c-4$ were about $380 \mathrm{bp}$, others from $X c$ 033, Xc-039, and Xct-90-01 were about $430 \mathrm{bp}$. None of these nonspecific products hybridized with the 360 -bp probe derived from $X a$.

Detection limit of the PCR protocol. The detection limit was $1.25 \mathrm{pg}$ (ethidium bromide staining) (Fig. 2A, lane 5) or 125 fg (blotted with the ${ }^{32} \mathrm{P}$-labeled Ala4/L1 probe) (Fig. 2B, lane 6) for genomic DNA. The detection limit approximated 0 to 5 $\mathrm{CFU}$ for either infected sugarcane sap (Fig. 2A, lanes 13 and 15) or leaf diffusate (Fig. 2B, lanes 21 and 27) and an average of 5 CFU for $X a$ suspension culture per PCR reaction (Fig. 2A, lane 31). Probing the Southern blots with the ${ }^{32} \mathrm{P}$-labeled Ala4/L1 probe apparently did not improve the detection limit except for genomic DNA (Fig. 2B). Compared with PCR, the detection limit of $\mathrm{Xa}$ by the dot blot serological assay was 17 and $73 \mathrm{CFU}$ for un-

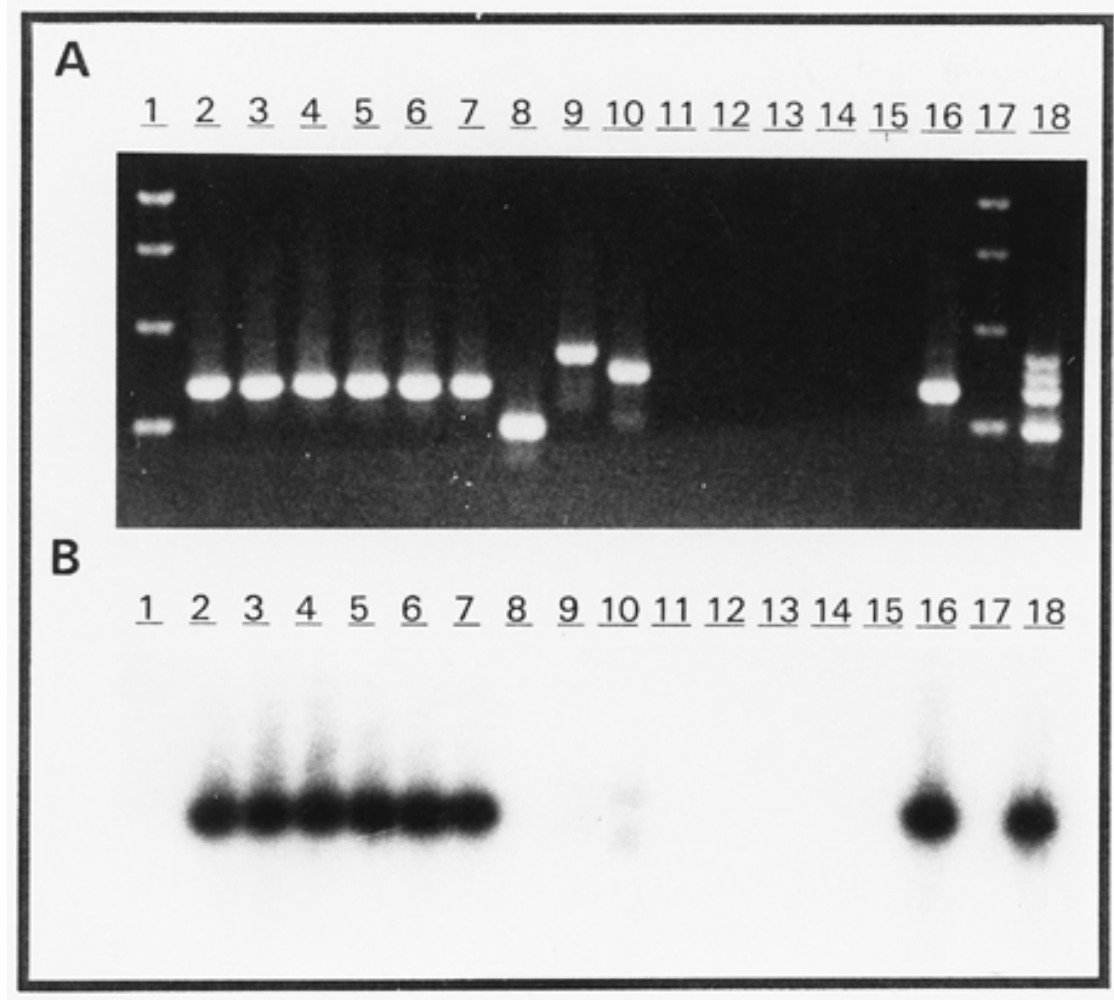

Fig. 1. (A) Ethidium bromide-stained polymerase chain reaction products (10 $\mu \mathrm{l}$ loading volume) following amplification with primer pair Ala4/L1 from genomic DNA of six Xanthomonas albilineans $(X a)$, Clavibacter xyli subsp. xyli, and seven sugarcane saprophytic bacterial strains. Lane designations: 1 and 17, molecular size markers (1,000,750,500, and $300 \mathrm{bp}$, respectively); 2 and 16, Xa1; 3, GT2; 4, 36KT; 5, 320KT; 6, 419KT; 7, Thiobd; 8, 243; 9, CA1; 10, 22-19-6s; 11, GT1; 12, 24-2i; 13, 22-25-6a; 14, 19-26-1a; 15, C. xyli subsp. xyli. Lane 18 contained $3 \mu$ each of PCR sample from $X a 1,243$, CA1, and 22-19-6s. (B) Autoradiograph of Southern blot of the gel in A probed with a ${ }^{32} \mathrm{P}-$ labeled Ala4/L1 fragment amplified from Xal genomic DNA (20 min exposure at room temperature). 
washed and washed sap, respectively (Fig. 2A, lanes 11 and 14), and 1,934 and 204 CFU for unwashed and washed leaf diffusate, respectively (Fig. 2A, lanes 18 and 24). Positive dot blot reactions were not observed for any suspension culture dilutions, which had as many as $791 \mathrm{CFU}$ (Fig. $2 \mathrm{~A}$, lanes 28 to 31 ).

PCR detection of $\mathrm{Xa}$ in infected sugarcane tissues. $X a$ was detected in all but one (Fig. 3A, lane 16) of the 16 sap sam- ples from symptomatic plants (Fig. 3A, lanes 16 to 31 ). Dot blot assay was also negative for the sap sample used in Figure $3 \mathrm{~A}$, lane 16. In addition, $X a$ was detected in 3 of 15 sap samples from asymptomatic plants (Fig. 3A, lanes 6, 8, and 14). Xa was not detected in any of the 15 controls, although a weakly amplified product of a saprophyte was detected in one plant (Fig. $3 \mathrm{~A}$, lane 36). $X a$ was detected by PCR in aliquots of the five randomly chosen sap samples not receiving the pretreatment washing. However, there was an apparent reduction in the yield of the 360-bp fragment among the aliquots not pretreated (Fig. 3B, lanes $8^{*}, 14^{*}, 18^{*}, 22^{*}$, and $25^{*}$ ), compared with the yield of the fragment among the aliquots receiving the pretreatment wash (Fig. 3B, lanes 8, 14, 18, 22, and 25).

In the leaf diffusate experiment, our PCR protocol detected $X a$ in all symptomatic samples, including nine from the
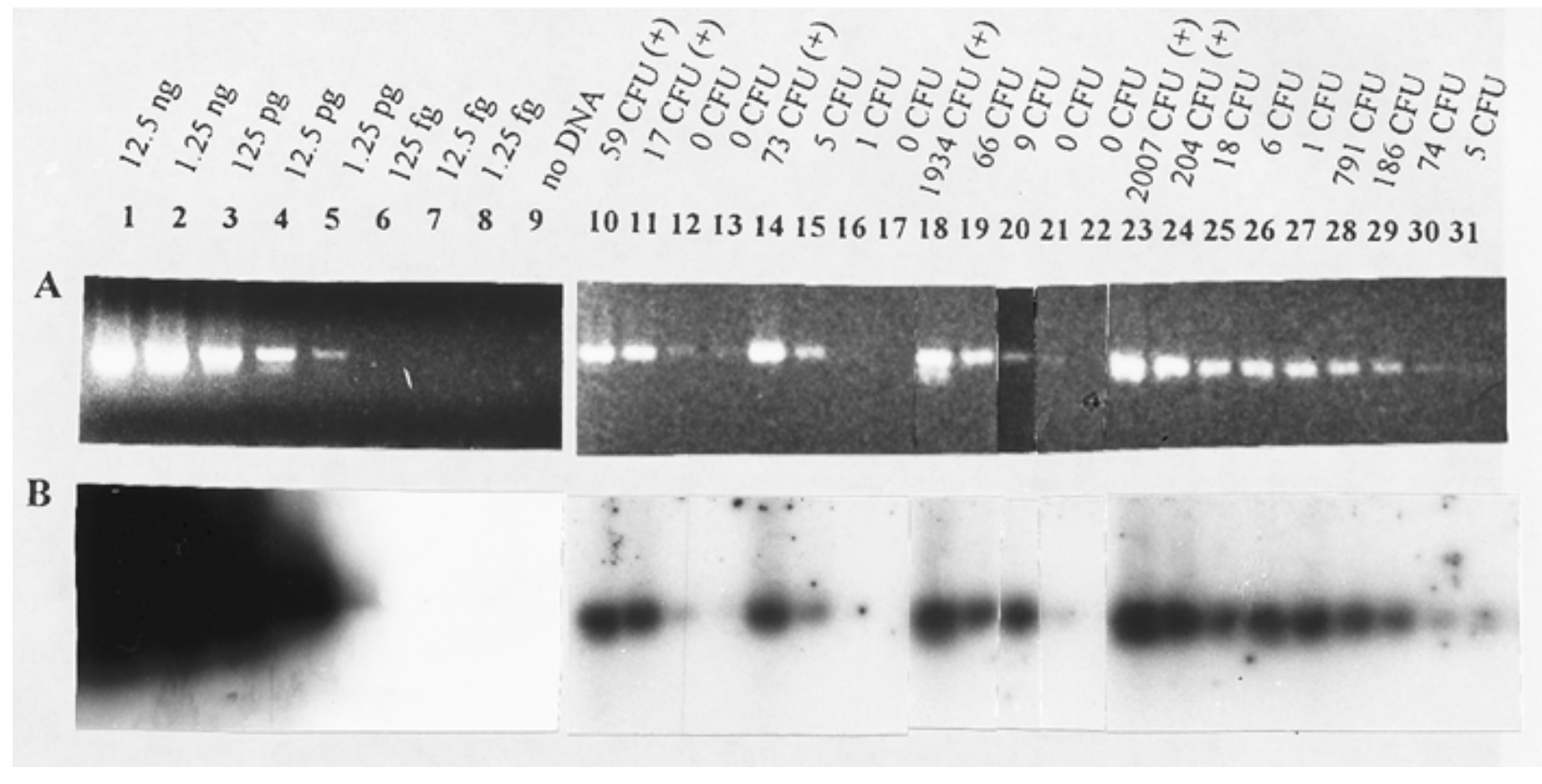

Fig. 2. (A) Ethidium bromide-stained polymerase chain reaction products following amplification with primers Ala4/L1 from 10-fold dilution series of either Xanthomonas albilineans strain Xal genomic DNA (lanes 1 to 9), or Xal-infected sugarcane sap (lanes 10 to 13, not prewashed; lanes 14 to 17, prewashed), or leaf diffusate (lanes 18 to 22, not prewashed; lanes 23 to 27, prewashed), or suspension culture (lanes 28 to 31 ). A (+) symbol indicates a positive dot-blot assay. (B) Autoradiographs of Southern blots of the gels in A probed with a ${ }^{32} \mathrm{P}-$ labeled Ala4/L1 fragment amplified from Xa1 genomic DNA.

\section{A}

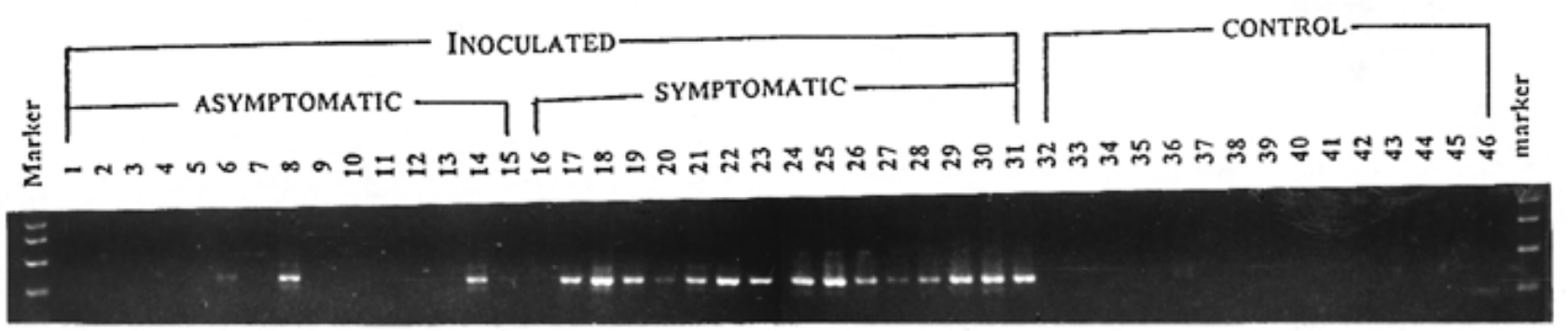

B

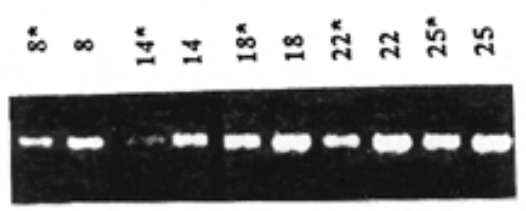

Fig. 3. (A) Ethidium bromide-stained polymerase chain reaction (PCR) products following amplification with primers Ala4/L1 from prewashed sap samples from: Xanthomonas albilineans (Xa)-inoculated but asymptomatic sugarcane plants (lanes 1 to 15 ); Xa-inoculated and symptomatic plants (lanes 16 to 31); and uninoculated control plants (lanes 32 to 46). Molecular size markers in side lanes are 1,000, 750, 500, and 300 bp, respectively. (B) Ethidium bromide-stained PCR products following amplification with primers Ala4/L1 from Xa-infected sap samples either without (lanes with * symbols) or with the wash pretreatment. Sample numbers correspond to those in $\mathbf{A}$. 
greenhouse and eight from the commercial field (Fig. 4, lanes with a [+] symbol). The protocol also detected $\mathrm{Xa}$ in five asymptomatic leaves from the greenhouse (Fig. 4, lanes $9,12,13,15$, and 19). No $X a$ was detected in the diffusate from the leaves with either the stretch of white line localized near the mid-rib (Fig. 4, lane 27) or the multiple stripes (Fig. 4, lane 24), confirming that these were not leaf scald symptoms.

\section{DISCUSSION}

The PCR protocol described in this paper was developed based on four published sets of primers located in or adjacent to the ITS region of bacterial $16 \mathrm{~S} / 23 \mathrm{~S}$ rRNA genes. Consensus primers L1/G1 (18), T3A/T5A (39), and T3A/T5B (39) were not specific for $X a$. Without the Perfect Match DNA polymerase enhancer, an additive that increases specificity and yield of PCR reactions by destabilizing mismatched primer-template complexes (Stratagene, La Jolla, CA), we were unable to get the 70-bp product from $\mathrm{Xa}$ with primers Ala4/Ile2 (14). However, when Ala4, which was $X a$-specific (14), was paired with L1, a unique 360-bp fragment was amplified from all $71 \mathrm{Xa}$ strains tested when PCR reactions were assembled on ice and started on a preheated $95^{\circ} \mathrm{C}$ thermal cycler. These $71 \mathrm{Xa}$ strains were geographically diverse and included representatives of the three known serovars, e.g., CP5, G44, and R8 of serovar I, HV5 and C1-35 of serovar II, and G7 and STK3 of serovar III (31). The ability to detect and identify diverse populations of $X a$ is important in applying a protocol to quarantine and routine diagnosis of $\mathrm{Xa}$. Our results suggest that little variation may have occurred within the ribosomal ITS region among different $X a$ strains.

Although no amplification products were observed from DNA templates of other xanthomonads, $C$. xyli subsp. xyli, and four sugarcane saprophytes (GT1, 24$2 \mathrm{i}, 19-26-1 \mathrm{a}$, and 23-25-6a), products of 280,420 , and 460 bp were amplified from three unidentified sugarcane saprophytes, namely, 243, 22-19-6s, and CA1, respec- tively. However, these products can be resolved by including a standard $\mathrm{X} a$ PCR product on both side lanes, or, if needed, by running a mixture of these products with the $X a$ PCR product as shown in Figure 1A, lane 18. Nonspecific annealing and amplification may also occur when PCR reactions are assembled at room temperature or when the thermal cycler is not preheated. In our study, such PCR conditions produced very faint, nonspecific bands from a few xanthomonads isolated from other plant species and a sugarcane saprophyte GT1, although none had a size of 360 bp (data not shown). Honeycutt et al. (14) also occasionally observed in Ala4/ Ile2-primed PCR a faint product of about 70 bp from $X$. campestris pv. vasculorum (ATCC 13901) and two Pseudomonas and one Acidovorax spp.

Our PCR protocol worked well not only with $X a$ genomic DNA samples, but also with $X a$ cells. The detection limit was 1.25 pg (ethidium bromide stain) or $125 \mathrm{fg}$ (Southern blot) $X a$ DNA, which is comparable to the $0.3 \mathrm{pg}$ DNA limit reported by Honeycutt et al. (14). We could detect as few as 0 to $5 \mathrm{Xa}$ cells per reaction in sap and leaf diffusate samples, or 3 to $5 X a$ cells in diluted suspension culture with ethidium bromide staining. The particular sap and leaf diffusate samples available when we were developing this protocol were not fresh but had been collected, treated with glycerol, and kept frozen for a period of time; therefore, an unknown portion of the $X a$ population might have died, resulting in underestimated CFU values. Positive PCR reactions found in a few dilutions where no colonies were recovered on XAS media may have resulted from DNA templates of dead $X a$ cells. The 360bp PCR product was also produced from $X a$ isolates that had been autoclaved (data not shown). In our study, the Southern blot hybridization was, in general, no more sensitive than ethidium bromide staining (Fig. 2 ). Dot blot assays were negative on any suspension culture dilutions that had as few as $791 \mathrm{CFU}$ per $0.1 \mathrm{ml}$, or about $8 \times$ $10^{3} \mathrm{CFU}$ per ml. According to Comstock and Irey (6), detection of $\mathrm{Xa}$ by dot and tissue blot is limited to $10^{5} \mathrm{CFU}$ per $\mathrm{ml}$. Thus, our PCR procedure was 10 to 100 times more sensitive than the dot blot serological assay (Fig. 2). It also appeared to be more sensitive than the one by Hartung et al. (12), which was limited to $25 \mathrm{pg}$ of $X$. campestris subsp. citri DNA or $10 \mathrm{CFU}$ per reaction with Southern blot hybridization. Li and De Boer (25) showed that the lower limit of detecting Clavibacter michiganensis subsp. sepedonicus was $5 \times$ $10^{2}$ to ${ }^{3} \mathrm{CFU} / \mathrm{ml}$ for PCR, $10^{4} \mathrm{CFU} / \mathrm{ml}$ for immunofluorescence, and $10^{5} \mathrm{CFU} / \mathrm{ml}$ for ELISA. The BIO-PCR procedure by Schaad et al. (33) improved sensitivity to 2 to $3 \mathrm{CFU} / \mathrm{ml}$ of original sample in detecting Pseudomonas syringae pv. phaseolicola. CFU only represents the live portion of a bacterial population in a biological sample and nondegraded DNA molecules from the dead cells are still good templates for PCR. It has been suggested that BIOPCR be used in phytosanitary applications (33) and caution be taken in comparing results from cell culture, serological, and PCR assay (10).

Our PCR protocol also worked on sap and leaf diffusate samples as $X a$ cells were detected in all but one of 16 sap and 17 leaf diffusate samples from symptomatic sugarcane plants. The advantage of using leaf diffusate is that the protocol is nondestructive and can detect $X a$ early in the sugarcane growing season. In addition, $X a$ was detected in three sap samples from asymptomatic plants and in five diffusate samples from asymptomatic leaves demonstrating cases of latent $\mathrm{Xa}$ infection. $\mathrm{Xa}$ cells were isolated from these samples and their identity was confirmed by PCR and immunological assays. Detection can be improved by concentrating $X a$ bacteria through centrifugation and by minimizing the volume of the final suspension. Two wash steps were incorporated into sap and diffusate sample preparations to help remove soluble substances that may inhibit PCR reaction (13). Residual components from sugarcane tissue may be inhibitory to the PCR reaction (data not shown; $\mathrm{S}$.

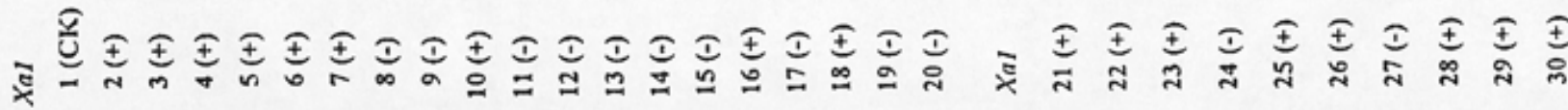
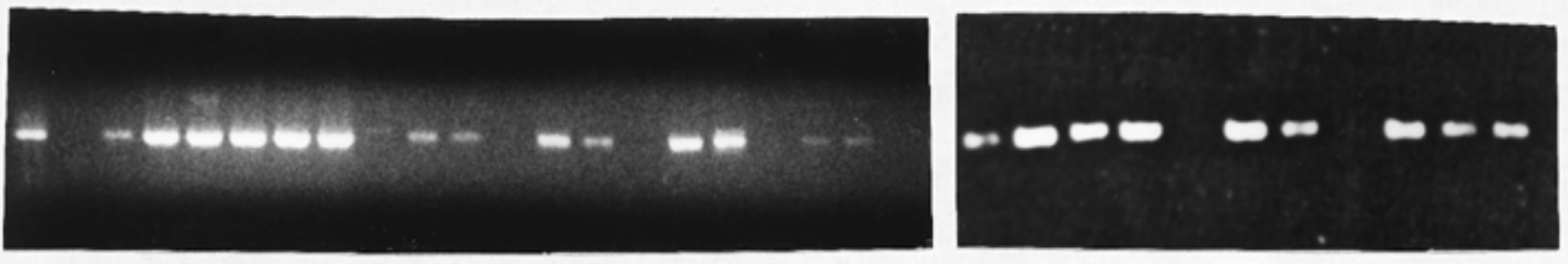

Fig. 4. Ethidium bromide-stained polymerase chain reaction products following amplification with primers Ala4/L1 from diffusate prepared from sugarcane leaves either asymptomatic (-), with typical pencil line symptom (+), or with atypical leaf symptoms (lane 27 , a stretch of white line localized to the mid rib; lane 24, multiple stripes). 
Lopes and K. E. Damann, Jr., unpublished). In this study, there was an apparent reduction in PCR amplification when $X a$ infected sap samples were not pre-washed. The inhibition appeared to be partial and could be circumvented through washing.

The PCR procedure by Honeycutt et al. (14), who used primer pair Ala4/Ile2, requires both AmpliTaq DNA polymerase (Perkin Elmer, Foster City, CA) and Perfect Match (Stratagene, La Jolla, CA). In addition, a 3\% NuSieve (FMC, Rockland, $\mathrm{ME)}$ agarose gel was used to resolve the 70-bp product. These requirements added significantly to the cost of the protocol. The most expensive material used in our PCR protocol is the native Taq DNA polymerase (Perkin Elmer, Foster City, CA). A $2 \%$ standard grade agarose gel or a $0.7 \%$ agarose $/ 0.65 \%$ Synergel could be used to resolve the 360 -bp product.

In conclusion, our PCR protocol is a simple, sensitive, and rapid procedure for detecting and identifying $X a$, the causal agent of sugarcane leaf scald disease. The protocol amplified a unique 360-bp product from all $71 \mathrm{Xa}$ strains in a worldwide collection regardless of serovar designation. The protocol worked directly on culture, sap, and leaf diffusate samples without the need of DNA extraction. Latent infections in asymptomatic plants could be detected within 1 day with PCR, whereas it could take several days to isolate $X a$ on XAS medium, which often required further confirmation tests. Due to unique 1-s denaturation and 1-s annealing, the PCR reaction can be completed in less than $2 \mathrm{~h}$. We expect that this PCR protocol can provide the sugarcane industry with a reliable molecular tool in the diagnosis of the leaf scald disease, thereby aiding in its control.

\section{ACKNOWLEDGMENTS}

We thank C. A. Clark (Louisiana State University, Baton Rouge, LA) for various $X a$ and other xanthomonad strains, J. C. Comstock (USDA/ ARS, Canal Point, FL), A. Dookun (Mauritius Sugar Industry Research Institute, Réduít, Mauritius), N. W. Schaad (USDA/ARS/FDWSR, Fort Detrick, MD), and S. Schenck (HSPA, Hawaii) for genomic DNA of various $X a$ strains. We also thank J. E. Leach (Kansas State University, Manhattan, KS) for genomic DNA of five Xoo strains, K. C. Ehrlich (USDA/ARS, New Orleans, LA) for Southern blot facility, M. J. Davis (University of Florida, IFAS-TREC, Homestead, FL) for polyclonal anti-Xa antibodies, K. E. Damann Jr. (Louisiana State University, Baton Rouge, LA), and R. J. Honeycutt, B. W. S. Sorbral, and M. McClelland (CIBR, San Diego, CA) for sharing unpublished information. K. Payne, Q. Wei, and S. Michalisko provided technical assistance.

\section{LITERATURE CITED}

1. Audy, P., Laroche, A., Saindon, G., Huang, H. C., and Gilbertson, R. L. 1994. Detection of the bean common blight bacteria, Xanthomonas campestris pv. phaseoli and X. c. phaseoli var. fuscans, using the polymerase chain reaction. Phytopathology 84:1185-1192.

2. Autrey, L. J. C., Dookun, A., and Saumtally, S. 1989. Improved serological methods for diagnosis of the leaf scald bacterium Xanthomonas albilineans. Proc. Int. Soc. Sugar Cane Technol. 20:704-713.
3. Autrey, L. J. C., Saumtally, S., Dookun, A., Sullivan, S., and Dhayan, S. 1994, Aerial transmission of the leaf scald pathogen, Xanthomonas albilineans. Proc. Int. Soc. Sugar Cane Technol. 21:508-524.

4. Barry, T., Colleran, G., Glennon, M., Dunican, L. K., and Gannon, F. 1991. The 16/23S ribosomal spacer region as a target for DNA probes to identify eubacteria. PCR Methods Applic. 1:51-56.

5. Braithwaite, K. S., Egeskov, N. M., and Smith, G. R. 1995. Detection of sugarcane bacilliform virus using the polymerase chain reaction. Plant Dis. 79:792-796.

6. Comstock, J. C., and Irey, M. S. 1992. Detection of the sugarcane leaf scald pathogen, Xanthomonas albilineans, using tissue blot immunoassay, ELISA, and isolation techniques. Plant Dis. 76:1033-1035.

7. Comstock, J. C., and Shine, J. M., Jr. 1992. Outbreak of leaf scald of sugarcane, caused by Xanthomonas albilineans, in Florida. Plant Dis. 76:426.

8. Davis, M. J., Rott, P., Baudin, P., and Dean, J. L. 1994. Evaluation of selective media and immunoassays for detection of Xanthomonas albilineans, causal agent of sugarcane leaf scald disease. Plant Dis. 78:78-82.

9. Davis, M. J., Rott, P., and Dean, J. L. 1994. Selective isolation of Xanthomonas albilineans, causal agent of leaf scald disease. Proc. Int. Soc. Sugar Cane Technol. 21:476-484.

10. De Boer, S. H., and Ward, L. J. 1995. PCR detection of Erwinia carotovora subsp. atroseptica associated with potato tissue. Phytopathology 85:854-858.

11. Grisham, M. P., Legendre, B. L., and Comstock, J. C. 1993. First report of leaf scald, caused by Xanthomonas albilineans, of sugarcane in Louisiana. Plant Dis. 77:537.

12. Hartung, J. S., Daniel, J. F., and Pruvost, O. P. 1993. Detection of Xanthomonas campestris pv. citri by the polymerase chain reaction. Appl. Environ. Microbiol. 59:1143-1148.

13. Henson, J. M., and French, R. 1993. The polymerase chain reaction and plant disease diagnosis. Annu. Rev. Phytopathol. 31:81-109.

14. Honeycutt, R. J., Sobral, B. W. S., and McClelland, M. 1995. tRNA intergenic spacers reveal polymorphisms diagnostic of Xanthomonas albilineans. Microbiology 141: 3229-3239.

15. Hoy, J. W., and Grisham, M. P. 1994. Sugarcane leaf scald distribution, symptomatology, and effect on yield in Louisiana. Plant Dis. 78:1083-1087.

16. Irey, M. S., and Comstock, J. C. 1991. Use of an enzyme-linked immunosorbent assay to detect the leaf scald pathogen, Xanthomonas albilineans, in sugarcane. J. Am. Soc. Sugar Cane Technol. 11:48-52.

17. Isakeit, T., and Irvine, J. E. 1995. First report of leaf scald, caused by Xanthomonas albilineans, of sugarcane in Texas. Plant Dis. 79:860.

18. Jensen, M. A., Webster, J. A., and Straus, N. 1993. Rapid identification of bacteria on the basis of polymerase chain reaction-amplified ribosomal DNA spacer polymorphisms. Appl. Environ. Microbiol. 59:945-952.

19. Klett, P., and Rott, P. 1994. Inoculum sources for the spread of leaf scald disease of sugarcane caused by Xanthomonas albilineans in Guadeloupe. J. Phytopathol. 142:283-291.

20. Koike, H. 1965. The aluminum-cap method for testing sugarcane varieties against leaf scald disease. Phytopathology 55:317-319.

21. Koike, H. 1968. Leaf scald of sugarcane in continental United States - a first report. Plant Dis. Rep. 52:646-649.

22. Lee, I.-M., Bertaccini, A., Vibio, M., and Gundersen, D. E. 1995. Detection of multiple phytoplasmas in perennial fruit trees with decline symptoms in Italy. Phytopathology 85: 728-735.
23. Leite, R. P., Jr., Minsavage, G. V., Bonas, U., and Stall, R. E. 1994. Detection and identification of phytopathogenic Xanthomonas strains by amplification of DNA sequences related to the hrp genes of Xanthomonas campestris pv. vesicatoria. Appl. Environ. Microbiol. 60:1068-1077.

24. Léoville, F., and Coléno, A. 1976. Détection de Xanthomonas albilineans (Ashby) Dowson, agent de l'échaudure de la canne à sucre, dans les boutures contaminées. Ann. Phytopathol. 8:233-236.

25. Li, X., and De Boer, S. H. 1995. Selection of polymerase chain reaction primers from an RNA intergenic spacer region for specific detection of Clavibacter michiganensis subsp. sepedonicus. Phytopathology 85:837-842.

26. Lockhart, B. E. L., Irey, M. S., and Comstock, J. C. 1996. Sugarcane bacilliform virus, sugarcane mild mosaic virus and sugarcane yellow leaf syndrome. In: Proc. Int. Workshop Sugar Cane Germplasm Conservation and Exchange. Aust. Ctr. Int. Agric. 67:108-112. Brisbane, Australia.

27. McClelland, M., Peterson, C., and Welsh, J. 1992. Length polymorphisms in tRNA intergenic spacers detected by using the polymerase chain reaction can distinguish streptococcal strains and species. J. Clin. Microbiol. 30:1499-1504.

28. Mullis, K. B., and Faloona, F. A. 1987. Specific synthesis of DNA in vitro via a polymerase-catalyzed chain reaction. Methods Enzymol. 155:335.

29. Ricaud, C., and Ryan, C.C. 1989. Leaf scald Pages 39-58 in: Diseases of Sugarcane. C. Ricaud, B. T. Egan, A. G. Gillispie, Jr., and C. G. Hughes, eds. Elsevier, Amsterdam.

30. Rott, P., Abel, M., Soupa, D., Feldmann, P., and Letourmy, P. 1994. Population dynamics of Xanthomonas albilineans in sugarcane plants as determined with an antibioticresistant mutant. Plant Dis. 78:241-247.

31. Rott, P., Arnaud, M., and Baudin, P. 1986. Serological and lysotypical variability of Xanthomonas albilineans (Ashby) Dowson, casual agent of sugarcane leaf scald disease. J. Phytopathol. 116:201-211.

32. Rott, P., Davis, M., and Baudin, P. 1994. Serological variability in Xanthomonas albilineans, causal agent of leaf scald disease of sugarcane. Plant Pathol. 43:344-349.

33. Schaad, N. W., Cheong, S. S., Tamaki, S., Hatziloukas, E., and Panopoulos, N. J. 1995. A combined biological and enzymatic amplification (BIO-PCR) technique to detect Pseudomonas syringae pv. phaseolicola in bean seed extracts. Phytopathology 85:243-248.

34. Schenck, S., and Alvarez, A. 1993. Identification and isolation of Xanthomonas albilineans from contaminated sources. Sugar Cane 1:2-6.

35. Smith, G. R., and Van de Velde, R. 1994. Detection of sugarcane mosaic virus and Fiji disease virus in diseased sugarcane using the polymerase chain reaction. Plant Dis. 78:557-561.

36. Southern, E. M. 1975. Detection of specific sequences among DNA fragments separated by gel electrophoresis. J. Mol. Biol. 98:503-517.

37. Tsai, C. C., Lin, C. P., and Chen, C. T. 1992. Application of monoclonal antibodies in the detection of Xanthomonas albilineans, the sugarcane leaf scald pathogen. Plant Pathol. Bull. 1:159-165.

38. Wahl, G. M., Stern, M., and Stark, G. R. 1979. Efficient transfer of large DNA fragments from agarose gels to diazobenzyloxymethyl-paper and rapid hybridization by using dextran sulfate. Proc. Natl. Acad. Sci. USA 76:3683-3687.

39. Welsh, J., and McClelland, M. 1991. Genomic fingerprints produced by PCR with consensus tRNA gene primers. Nucleic Acids Res. 19:861-866. 